\title{
Penggunaan Insulin Basal dalam Praktek Sehari-hari: Panduan Praktis untuk Dokter Umum
}

\author{
Dani Rosdiana*
}

\begin{abstract}
Prevalence of diabetes mellitus in Riau have reached 10,4 \%, it's higher than national pravelence. Hence, it's need more attention from physician. The important thing in managing DM is how to restrain controlled blood sugar level. The best parameter to evaluate controlled blood sugar level is level of HbA1c. Fasting blood glucose is one of important component which determine HbA1c especially HbA1c more than $8,5 \%$. There are some pharmacology agent to decrease HbA1c level, and insulin is the most effective agent. Why physician needs insulin?

It was caused by impairment of betha cell pancreas was directly propotional with DM progressiveness. Comprehension and capability for using basal insulin are important to physician, not only for internist but also for general practinioner. As we know that general practinioner have a competency to manage DM without complication. Guidance for using simple and practical basal insulin is expected will facilitate physician to manage blood sugar level of DM patient.
\end{abstract}

Keywords: Diabetes mellitus (DM), Kadar HbA1c, Basal insulin

Diabetes melitus (DM) merupakan salah satu penyakit yang jumlahnya akan terus meningkat. World Health Organization (WHO) memprediksi kenaikan pasien diabetes Indonesia dari 8,4 juta pada 2000 menjadi sekitar 21,3 juta pada $2030{ }^{1}$. Prevalensi DM di Riau termasuk tinggi di Indonesia, yaitu sekitar 10,4\% jauh diatas angka nasional sebesar 5\% 2. Baik IDF (International Diabetes Federation) maupun WHO memperkirakan terjadi peningkatan penyandang diabetes sebanyak 2-3 kali lipat pada tahun $2030{ }^{3}$.

Diabetes Militus merupakan penyakit kronik progresif, dimana progresifitas kerusakan sel betha pancreas berbanding lurus dengan lamanya timbulnya penyakit dari onset. Diperkirakan sisa sel betha pankreas pada tahun ke 10 sejak onset DM tidak lebih dari 20\%. Pemberian insulin eksogen dengan memperhatikan profil insulin endogen memberikan banyak manfaat bagi pasien ${ }^{2,4}$.

\footnotetext{
* Coresponding Author:

Bagian Ilmu Penyakit Dalam, Fakultas Kedokteran Universitas Riau, RSU Arifin Ahmad.

Jl. Diponegoro No 1, Pekanbaru.
}

Mengingat dampak buruk terhadap kualitas hidup diabetesi. Peran dokter umum sebagai ujung tombak di pelayanan primer menempati peran strategis dalam mengelola DM. Kasus DM tanpa penyulit dapat dikelola tuntas oleh dokter umum di pelayanan kesehatan dasar. Kenyataan di lapangan, dokter umum merawat $>75 \%$ pasien DM. Dengan ditemukan dua insulin analog, nampaknya pengetahuan dan ketrampilan dokter umum sangat diperlukan. Pengetahuan dasar mengenai terapi insulin meliputi jenis, farmakokinetik, rejimen, keuntungan, keamanan dan efek samping wajib dikuasai oleh dokter umum. Insulin basal dengan profil tanpa waktu puncak dan risiko hipoglikemi minimal merupakan salah satu pilihan dalam mengendalikan gula darah puasa yang buruk ${ }^{4,5}$.

\section{KLASIFIKASI DM}

Diabetes mellitus menurut ADA (American Diabetes Association) 2010 adalah penyakit metabolik dengan karakteristik hiperglikemia yang terjadi karena kelainan sekresi insulin, kerja insulin atau keduanya. Hiperglikemia kronik berhubungan 
dengan komplikasi dan kerusakan jangka panjang beberapa organ tubuh, terutama mata, ginjal, saraf, jantung dan pembuluh darah ${ }^{6}$.

Diabetes melitus diklasifikasikan oleh American Diabetes Association (ADA) 2010, berdasarkan etiologi yang mendasari terjadinya hiperglikemia menjadi:

- Diabetes melitus tipe 1 (Destruksi sel â umumnya menjurus ke arah defisiensi insulin absolut).
A. Melalui proses imunologik (Otoimunologik)
B. Idiopatik

- Diabetes melitus tipe 2 (Bervariasi, mulai yang dominan resistensi insulin disertai defisiensi insulin relatif sampai yang dominan gangguan sekresi insulin bersama resistensi insulin).

\section{- Diabetes melitus tipe lain}
A. Defek genetik fungsi sel â
B. Defek genetik kerja insulin
C. Penyakit eksokrin pancreas
D. Endokrinopati
E. Karena obat/zat kimia
F. Infeksi
G. Sebab imunologi yang jarang
H. Sindroma genetik lain yang berhubungan dengan DM

\section{- Diabetes melitus gestasional}

Diabetes melitus yang muncul pada masa kehamilan, umumnya bersifat sementara, tetapi merupakan faktor risiko untuk DM Tipe $2^{4,7}$.

\section{DIAGNOSIS DM}

Diagnosis klinis DM umumnya akan dipikirkan apabila ada keluhan khas DM berupa poliuria, polidipsia, polifagia dan penurunan berat badan yang tidak dapat dijelaskan penyebabnya. Keluhan lain yang mungkin disampaikan penderita antara lain badan terasa lemah, sering kesemutan, gatal-gatal, mata kabur, disfungsi ereksi pada pria dan pruritus vulva pada wanita. Apabila ada keluhan khas, hasil pemeriksaan kadar glukosa darah sewaktu > $200 \mathrm{mg} / \mathrm{dl}$ sudah cukup untuk menegakkan diagnosis DM. Hasil pemeriksaan kadar glukosa darah puasa $>126 \mathrm{mg} / \mathrm{dl}$ juga dapat digunakan sebagai patokan diagnosis DM. Pemeriksaan diagnostik dilanjutkan untuk menentukan kadar glukosa darah pasien sesuai dengan bagan (Gambar 1) ${ }^{1}$.

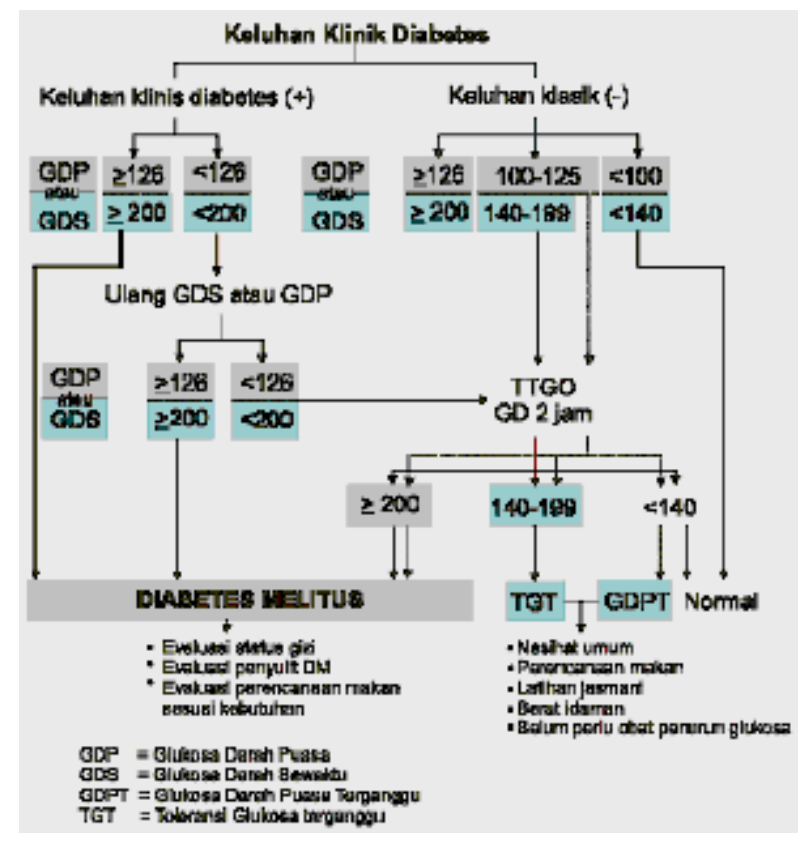

Gambar 1. Langkah-langkah diagnosis DM

\section{TERAPI INSULIN}

\section{Sejarah dan Jenis Insulin}

Penatalaksanaan DM secara konvensional melalui tahap demi tahap dimulai dengan pendekatan modifikasi gaya hidup (diet dan olah raga), obat-obat anti diabetik oral tunggal, obat anti diabetika kombinasi hingga insulin. Namun, sayangnya pasien sering datang ke dokter sudah dengan komplikasi yang menyertainya akibat kontrol gula darah yang buruk. Pengenalan insulin pada awal terjadinya DM sering ditolak dengan berbagai alasan/keterbatasan mulai dari ketakutan dari diri pasien hingga biaya yang cukup tinggi. Beberapa studi menunjukkan pemberian insulin lebih dini memberikan hasil luaran (outcome) yang lebih baik. ${ }^{4,5,8}$

Insulin adalah salah satu obat yang digunakan untuk pengendalian hiperglikemia. Sejak ditemukan hampir 90 tahun yang lalu, insulin merupakan salah 
satu tonggak bersejarah dalam bidang kedokteran di abad 20. Awalnya insulin dibuat dari ekstrak binatang, seperti babi dan sapi. Kemudian dengan kemajuan teknologi berhasil dibuat insulin manusia (human insulin) pada tahun 1980 an. Seiring dengan perkembangan teknologi pada tahun 1990-an, diperkenalkan insulin analog. Salah satu kelebihan insulin adalah kemampuannya dalam menekan mediator inflamasi lebih banyak dibandingkan dengan obat-obat hipoglikemik oral. Insulin juga paling efektif menurunkan glukosa darah dan bisa digunakan dengan dosis adekuat dapat menurunkan kadar HbA1C sesuai target yang diinginkan ${ }^{5,9}$.

Berdasarkan lama kerja, insulin manusia (human insulin dan insulin analog) terbagi menjadi 4 jenis yaitu:

1. Insulin kerja cepat (rapid acting insulin)-insulin analog: kerja awal 0,2-0,5 jam dengan waktu puncak mencapai $0,5-2$ jam

2. Insulin kerja pendek (short acting insulin)human insulin : kerja awal 0,5-1 jam dengan waktu puncak mencapai $0,5-1$ jam

3. Insulin kerja menengah (intermediate acting insulin)- human insulin, NPH: kerja awal 1,5-4 jam dengan waktu puncak mencapai 4-10 jam

Insulin campuran kerja tetap, kerja pendek dan menengah (Premixed insulin)

4. Insulin kerja panjang (long acting insulin)insulin analog: kerja awal 1-3 jam tanpa waktu puncak (no peakless) ${ }^{5}$.

\section{Efek Insulin}

Terapi insulin selain mempunyai efek metabolik terhadap metabolism karbohidrat, protein dan lipid, juga memiliki efek-efek yang lain didalam tubuh kita. Insulin memiliki efek anti inflamasi dengan menekan faktor transkrip pro inflamasi seperti nuclear factor (NF)-kB, Egr-1 dan activating protein-1 (AP-1). Insulin juga bermanfaat dalam menurunkan kadar triasilgliserol dan meningkatkan kadar kolesterol HDL walaupun pada pasien obese, khususnya pada pasien-pasien dengan pengendalian glukosa darah yang buruk. Seperti kita ketahui bahwa salah satu efek samping insulin adalah kenaikan berat badan disamping hipoglikemia ${ }^{10}$.

\section{Indikasi Pemberian Terapi Insulin}

Terapi insulin klasik diindikasikan pada kondisi-kondisi seperti DM tipe 1, hipoglikemia pada critically ill, infeksi berat: tuberculosis paru, kaki diabetik terinfeksi, berat badan kurang, DM gestasional, dan kendali glukosa darah buruk. Menurut panduan pengobatan DM tipe 2 dari American Diabetes Association, terapi insulin merupakan salah satu pilihan tambahan bila langkah pertama pengobatan dengan kombinasi gaya hidup dan metformin gagal mencapai target $\mathrm{HbA} 1 \mathrm{C}$ yang diinginkan yaitu $<7 \%^{5,11,12}$.

\section{Konsep Insulin Basal dan Insulin Prandial}

Pada orang normal, jumlah insulin yang diekskresikan oleh sel betha (endogen) terutama dipengaruhi oleh keadaan puasa dan makan. Pada keadaan puasa, sel betha mensekresi insulin pada kadar tertentu yang hampir sama sepanjang waktu puasa dan sebelum makan. Konsep ini disebut dengan insulin basal yaitu bertujuan mempertahankan kadar gula darah puasa pada orang normal dibawah $100 \mathrm{mg} / \mathrm{dl}$. Setiap kali makan ketika glukosa darah naik akibat asupan dari luar, dibutuhkan sekresi insulin secara cepat oleh sel betha pankreas, ini yang disebut dengan insulin prandial ${ }^{5}$.

Pada diabetisi, terjadi kekurangan baik insulin basal maupun insulin prandial endogen. Berdasarkan konsep tersebut, sediaan insulin eksogen disesuaikan dengan kebutuhan seperti orang normal yaitu insulin basal dan prandial. Insulin basal (kerja panjang atau menengah) diberikan sebanyak 1-2 kali sehari ${ }^{5}$.

\section{Insulin Basal}

Tersedia insulin basal berupa insulin NPH manusia (kerja menengah atau intermediate), insulin analog glargine dan detemir (kerja panjang). Dibandingkan dengan insulin basal analog, insulin basal NPH mempunyai variasi penyerapan yang lebih lebar dari hari ke hari sehingga kurang memadai dipakai sebagai insulin basal yang diharapkan dapat bekerja selama 24 jam. Efek hipoglikemia yang mungkin diakibatkan oleh insulin intermediate juga lebih besar dibandingkan insulin 
analog. Sehingga insulin basal analog aman dipilih untuk menurunkan kadar gula darah puasa (sebagai kontributor $\mathrm{HbA1c}$ ) karena efek hipoglikemiknya paling minimal dibanding insulin yang lain dan dapat menurunkan $\mathrm{HbA} 1 \mathrm{c}$ hingga 2\%. Kapan dipilih insulin analog? Terutama jika kadar gula darah puasa sulit dikendalikan dengan modifikasi gaya hidup dan obat anti diabetika oral seperti metformin atau kombinasi metformin dengan obat jenis lainnya 5,9 .

Insulin glargine merupakan insulin analog dengan dua modifikasi terhadap insulin manusia. Modifikasi pertama dengan menambahkan dua molekul arginine ke rantai B sehingga menaikkan pH dari 5,4 menjadi 6,7 menjadikan molekul menjadi mudah larut dan keasamannya berkurang. Modifikasi kedua adalah mengganti aspargin dengan glisin sehingga lebih stabil. Keuntungannya adalah kadar didalam darah konstan selama 24 jam namun tidak ada fase puncak (no peakless) ${ }^{5}$.

Pemberian insulin basal secara praktis yaitu : dosis insulin basal pada awal pemberian adalah 10 unit per hari (asumsi berat bandan $50 \mathrm{~kg}$ ) atau 0,2 unit/KgBB, yang dapat diberikan pada saat sebelum tidur (kerja menengah atau panjang) atau pagi hari (kerja panjang). Untuk penyesuian dosis harian, dosis insulin dapat dinaikkan 2 unit setiap 3 hari jika sasaran glukosa darah puasa belum tercapai (antara $70-130 \mathrm{mg} / \mathrm{dl}$ ), dan dapat juga dinaikkan 4 unit setiap tiga hari jika kadar gula darah puasa diatas $180 \mathrm{mg} / \mathrm{dl}$. Bila terjadi hipoglikemia atau kadar glukosa darah $<70 \mathrm{mg} / \mathrm{dl}$, dosis insulin basal malam dapat dikurangi 4 unit atau lebih kurang $10 \%$ dari dosis sebelumnya.

Tabel 1. Cara praktis penyesuaian dosis insulin basal

\begin{tabular}{cl}
\hline Kadar gula darah puasa $(\mathrm{mg} / \mathrm{d} 1)$ & \multicolumn{1}{c}{ Dosis insul in basal } \\
\hline$<70$ & Tununkan dosis 2 unit \\
$70-130$ & Pertahankan dosis \\
$131-180$ & Naikkan dosis 2 unit setiap 3 hari \\
$>180$ & Naikkan dosis 4 unit setiap 3 hari \\
\hline
\end{tabular}

Bila target HbA1C tercapai $(<7 \%)$ setelah terapi selama 3 bulan maka terapi dapat diteruskan dan HbA1C sebaiknya diperiksa setiap 3 bulan. Namun sebaiknya, bila target HbA1C tidak tercapai (>7\%) setelah terapi selama 3 bulan maka perlu dilakukan beberapa langkah sebagai berikut. Jika glukosa darah puasa dalam kisaran target (70$130 \mathrm{mg} / \mathrm{dl}$ ), maka harus dilakukan pemeriksaan glukosa darah sebelum makan siang, makan malam dan tidur malam diluar kisaran target maka perlu ditambahkan insulin kerja cepat masing-masing pada saat makan pagi, makan siang dan makan malam, biasanya dapat dimulai dengan dosis 4 unit dan dapat dinaikkan sebesar 2 unit per 3 hari hingga target glukosa darah tercapai. Jika dalam waktu 3 bulan target tetap tidak tercapai, maka glukosa darah sebelum makan perlu diperiksa kembali dan jika hasilnya tetap diluar kisaran target maka diperlukan injeksi tambahan. Jika target HbA1C tetap tidak tercapai maka periksa glukosa darah 2 jam post prandial dan dosis insulin preprandial dapat dinaikkan. Sebagai dokter umum paling tidak dapat menguasai ketrampilan dalam memberikan insulin basal. Jika dengan penatalaksanaan berupa pilar: modifikasi gaya hidup, olah raga, kombinasi obat anti diabetika oral dan insulin basal tidak berhasil mencapai target, pasien dapat dirujuk ke pelayanan kesehatan sekunder atau tertier ${ }^{5,12}$.

\section{Cara Pemberian Insulin}

Cara pemberian insulin yang umum dilakukan adalah dengan spuit insulin $1 \mathrm{cc}$ dan jarum pen insulin atau pompa insulin. Penggunaan insulin saat ini lebih mudah dan nyaman dengan ditemukan pen insulin. Penggunaannya lebih mudah, dan nyaman dibanding jarum dan spuit. Pengaturan dosis lebih akurat dan lebih flexible karena dapat dibawa kemana-mana dengan mudah. Pemberian insulin diberikan secara subkutan di area seperti sekitar pusat (tempat terbaik), paha dan lengan atas ${ }^{5}$.

Efek samping yang harus diperhatikan adalah efek hipoglikemia sekalipun insulin basal tidak ada kadar puncak. Edukasi kepada pasien mengenai gejala dan tanda-tanda hipoglikemia seperti: mual, 
muntah, sakit kepala, keluar keringat dingin, rasa berputar dan melayang, rasa lapar, hingga gangguan kesadaran wajib diingatkan. Selain itu tata cara pertolongan pertama pada pasien dengan hipoglikemia juga penting disampaikan kepada pasien yaitu dengan memberikan glukosa murni sebanyak 20 gram jika pasien masih sadar ${ }^{5}$.

\section{KESIMPULAN}

Pengendalian kadar glukosa yang buruk merupakan tantangan bagi klinisi dalam mengelola pasien DM. Dokter umum yang berperan strategis di pelayanan primer merupakan tumpuan dalam pengelolaan dan pencegahan DM. Pengetahuan dan ketrampilan dalam pemakaian insulin terutama insulin basal merupakan issue yang penting diketahui dan dikuasai oleh dokter umum. Insulin basal analog dengan sediaan dan cara pemberian yang mudah dan nyaman serta panduan yang praktis menjadi pilihan bagi pasien dengan kadar gula darah yang tidak terkendali. Pemakaian rumus 2-0-2 sesuai panduan dari Perkeni memudahkan dokter umum dalam mengelola pasien pasien DM.

\section{DAFTAR PUSTAKA}

1. Konsensus Pengelolaan dan Pencegahan Diabetes Melitus tipe 2 di Indonesia, Perkeni, 2011.

2. Riset Kesehatan Dasar 2013.

3. Wild $\mathrm{S}$ et all. Global prevalence of diabetes. Estimates for the year 2000 and Projection for 2030. 2004. Diab care. 27:1047-1053.

4. American Diabetes Association. Position Statement:Standards of Medical Care in Diabetes 2010. Diab Care;33.

5. Terapi Insulin pada Pasien Diabetes Mellitus, Perkeni, 2011.

6. Sudoyo AW, Setiyohadi B, Alwi I, Simadibrata M, Setiati S. Buku ajar ilmu penyakit dalam. Jil III. th $^{\text {th }}$ ed. Jakarta: Pusat Penerbitan Ilmu Penyakit Dalam FKUI; 2007.

7. Jameson BF. Harrison's principal internal medicine. $16^{\text {th }}$ ed. United States: The Mc GrawHill Company; 2004.
8. Inzucchi et al. New position statement of the ADA and EASD on management of hyperglycemia in type 2 diabetes. Diabetologia. Published 2010.

9. IDF Treatment Algorithm. International Diabetes Federation 2011. http://www.idf.org/ treatment-algorithm-people-type-2-diabetes

10.Dandona P, Aljada A, Chaudhuri A, Mohanty P, Garg R. Metabolic Syndrome. A comprehensive perspective based on interaction between obesity, diabetes, and inflammation. Circulation 2005; 111: 1448-1454.

11.Herbst KL et al. Insulin strategies for primary care providers. Clinical diabetes. 2002, 20 (1).

12. White JR. Clarifying the role of insulin in type 2 diabetes management. Clinical diabetes. 2003, 21 (1). 